
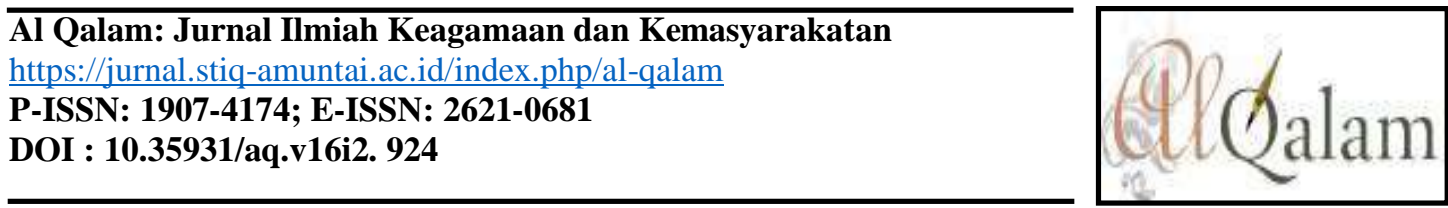

\title{
KOMUNIKASI TEURAPEUTIK DEWAN GURU DALAM MEMBINA SANTRI YANG MELANGGAR PERATURAN \\ (Studi Di Jamiah Al-Aziziyah Desa Batee Iliek Kecamatan Samalanga)
}

\author{
Zulfikar \\ Institut Agama Islam (IAI) Al-Aziziyah Samalanga Bireuen Aceh \\ zulfikar@iaialaziziyah.ac.id
}

\begin{abstract}
Abstrak
Tulisan ini ingin mengkaji tentang Komunikasi Teurapeutik kemampuan atau ketrampilan seorang perawat untuk membantu klien untuk beradaptasi terhadap stress, mengatasi gangguan psikologis dan belajar bagaimana berhubungan dengan orang lain. Penelitian ini bertujuan untuk mengetahui bagaimana komunikasi teurapeutik dewan guru Dayah Jamiah Al-Aziziyah dalam menanggani santri yang melanggar aturan yang sudah ditetapkan oleh pihak Dayah Jamiah AlAziziyah selama ini, sehingga akan memberikan sebuah jawaban bagaimana bnetuk komunikasi teurapeutik yang dilakukan oleh dewan guru di Dayah Jamiah Al-Aziziyah dalam menanggani santri yang melanggar peraturan. Dalam penelitian ini, peneliti menggunakan single-case study design, karena tujuan penelitian ini adalah untuk memperoleh informasi menyeluruh secara detail dan pemahaman tentang bagaimana komunikasi teurapeutik dewan guru dalam meanggani santri yang melanggar peraturan, sehingga santri tersebut tidak mengulang kembali kesalahan yang telah dilakukan dan berubah menjadi santri yang patuh terhadap aturan yang telah diterapkan. Komunikasi teurapeutik ini menjadi salah satu solusi bagi dewan guru di Dayah Jamiah AlAziziyah dalam menanggani santri yang telah melanggar, juga menjadi salah satu metode untuk santri baru agar tidak melanggar segala bentuk peraturan yang telah ditetapkan oleh pihak pengurus dayah atau pesantren. Dengan adanyan komunikasi terupeutik yang dilakukan oleh dewan guru Dayah Jamiah Al-Aziziyah, maka diharapkan tidak banyak lagi santri yang melanggar dan bagi santri yang melanggar akan menjadi sebuah pembelajaran bagi mereka, sehingga mereka berubah dan menjadi santri yang baik dan patuh dengan segala aturan yang telah diterapkan.
\end{abstract}

Kata Kunci: Komunikasi Teurapeutik, Dewan Guru, Santri, Melanggar

\section{PENDAHULUAN}

Dayah atau pesantren merupakan lembaga yang mengelola pendidikan formal maupun pendidikan non formal, di Provinsi Aceh dayah merupakan lembaga pendidikan yang sangat digemari oleh para orang tua dan banyak orang tua yang memilih lembaga pendidikan dayah atau pesantren sebagai tempat lanjutan pendidikan bagi anak mereka. Selain dayah atau pesantren saat

Al Qalam: Jurnal Ilmiah Keagamaan dan Kemasyarakatan Vol. 16, No. 2 Maret - April 2022 
Zulfikar : Komunikasi Teurapeutik Dewan Guru Dalam Membina Santri Yang Melanggar Peraturan (Studi di Jamiah Al-Aiziyah Desa Batee Iliek Kecamatan Samalanga)

ini sudah memilik pendidikan formal akan tetapi ada alasan lain bagi para orangtua dalam memilih lembaga pendidikan dayah yaitu bahwa di dayah adalah tempat membentuk karakter pendidikan anak dan anak juga lebih mudah dalam melakukan pengawasan.

Salah satu problem yang dihadapi oleh dunia pendidikan dayah pada saat ini adalah santri, karena santri mempunyai karakteristik yang unik karena setiap santri itu punya karakter berbedabeda, tentu dalam melakukan pembinaan dan penangganan santri juga akan berbeda antara satu santri dengan santri yang lain. Pihak pengelola dayah dalam menganggani problem yang terjadi dalam lingkungan dayah tentu perlu cara-cara tertentu ataupun metode yang dianggap paling efektif dalam menyelesaikan prolematika dalam dunia pendidikan dayah, salah satu metode yang paling efekti yaitu adanya komunikasi antara pengelola dayah dengan santri atau wali santri.

Komunikasi interpersonal yang disebut juga komunikasi Terapeutik merupakan komunikasi yang dilakukan secara sadar, bertujuan untuk meningkatkan kesehatan dan kegiatannya dipusatkan untuk kesembuhan pasien. ${ }^{1}$ Komunikasi terapeutik tidak dapat berlangsung dengan sendirinya, tetapi harus direncanakan, dipertimbangkan dan dilaksanakan secara professional. Komunikasi terapeutik memegang peranan penting dalam membantu pasien dalam memecahkan masalah yang dihadapi. Komunikasi terapeutik adalah komunikasi antara orang-orang secara tatap muka yang memungkinkan setiap pesertanya menangkap reaksi orang lain secara langsung, baik dilakukan secera verbal maupun non-verbal. ${ }^{2}$

Defenisi lain menyebutkan bahwa komunikasi terapeutik merupakan suatu teknik dalam usaha mengajak pasien dan keluarga bertukar pikiran dan perasaan. ${ }^{3}$ Teknik tersebut mencakup keterampilan berkomunikasi secara verbal dan non-verbal. Potter dan Perry menyatakan bahwa keterampilan berkomunikasi ada dua cara yaitu, komunikasi verbal dan non-verbal. Komunikasi verbal termasuk kedalam penggunaan kata-kata atau tulisan dan sangat dipengaruhi oleh beberapa faktor, yaitu kemaknaan, perbendaharaan kata, kecepatan, intonasi/nada suara, kejelasan dan keringkasan, waktu dan relevansi. Sedangkan komunikasi yang bersifat non-verbal merupakan ungkapan yang berupa isyarat-isyarat, bahasa tubuh yang dipengaruhi oleh beberapa faktor yaitu, penampilan, postur dan cara berjalan, ekspresi wajah, isyarat/gerak tangan, pandangan, sentuhan dan jarak tubuh dan kedekatan. ${ }^{4}$

h. 11 .

\footnotetext{
${ }^{1}$ Anas Tamsuri, Komunikasi dalam Keperawatan, (Jakarta: Penerbit Buku Kedokteran EGC, 2004),

${ }^{2}$ Deddy Mulaya, Ilmu Komunikasi Suatu Pengantar, (Bandung: Remaja Rosdakarya, 2002), h. 73.

${ }^{3}$ Anas Tamsuri, Komunikasi dalam Keperawatan..., h. 12.

${ }^{4}$ Arwani, Komaunikasi dalam Keperawatan, (Jakarta: EGC, 2002), h. 19-30.
}

Al Qalam: Jurnal Ilmiah Keagamaan dan Kemasyarakatan Vol. 16, No. 2 Maret - April 2022 
Zulfikar : Komunikasi Teurapeutik Dewan Guru Dalam Membina Santri Yang Melanggar Peraturan (Studi di Jamiah Al-Aiziyah Desa Batee Iliek Kecamatan Samalanga)

Dayah Jamiah Al-Aziziyah yang terletak di di Dusun Meunasah Leupee Desa Batee Iliek Kecamatan Samalanga Kabupaten Bireuen Provinsi Aceh merupakan salah satu dayah yang berkembang dengan pesat dalam beberapa tahun ini, hal itu dapat dilihat dari jumlah santriwan/wati yang sudah mondok di dayah tersebut. Dayah Jamiah Al-Aziziyah merupakan dayah yang memadukan dua model pendidikan yaitu antara pendidikan formal dan non-formal, dimana pengajaran kitab kuning menjadi pilihan utama dan pendidikan umum menjadi pendukung untuk memajukan roda pendidikan di dayah tersebut. Dayah Jamiah Al-Aziziyah yang terus berkembang dan maju tidak terlepas dari berbagai problem dan persoalan yang sedang dihadapi oleh pengelola dayah dan dewan guru, masalah terbesar yang sedang dihadapi saat ini adalah tentang menanggani santri yang tidak disiplin dan melanggar peraturan dayah tersebut.

Penelitian ini diharapkan mampu memberikan jawaban bagaimana komunikasi terapeutik dewan guru ketika berkomunikasi dengan santri dan orangtua santri dalam menangani pelanggaran yang dilakukan oleh santri, sehingga mampu menyelesaikan persoalan santri yang melanggar. Pelanggaran yang selama ini dilakukan oleh santri Dayah Jamiah Al-Aziziyah ada yang katagorinya berat dan ada katagori ringan, pelanggaran dengan katagori ringan inilah yang menjadi fokus komunikasi terapeutik yang dilakukan oleh dewan guru dengan santi dan wali santri.

Dalam penelitian ini peneliti berpedoman pada beberapa literatur hasil penelitian sebelumnya yang relevan dengan komunikasi terapeutik yang telah dilakukan oleh peneliti-peneliti sebelumnya, dimana penelitian itu berkaitan erat dengan komunikasi terapeutik walaupun objeknya sedikit berbeda. Terdapat beberapa penelitian yang relevan dengan komunikasi terapeutik dalam menanggani santri yang melanggar, antara lain sebagai berikut :

Buku karya Mundakir, yang menyebutkan bahwa dalam menanggapi pesan yang disampaikan oleh klien, perawat dapat menggunakan berbagai teknik komunikasi sebagai berikut, yaitu dengan (1) Mendegar, (2) Pertanyaan terbuka, (3) Mengulang, (4) Klarifikasi, (5) Refleksi, Menfokuskan, (7) Membagi Persepsi, (8) Identifikasi Tema, (9) Diam, (10) Informing dan (11) Saran. ${ }^{5}$

Selanjutnya buku Tri Anjaswani, menjelaskan bahwa pada usia remaja, perkembangan komunikasinya ditunjukkan dengan kemampuan berdiskusi atau berdebat. Pola perkembangan kognisinya sudah mulai berpikir secara konseptual mengingat masa ini adalah masa peralihan anak menjadi dewasa. Remaja sering kali merenungi kehidupannya yaitu tentang masa depan yang direfleksikan dalam komunikasi. Berikut sikap komunikasi terapeutik yang harus dikembangkan perawat saat berinteraksi dan berkomunikasi dengan remaja, yaitu (1) Menjadi pendengar yang

${ }^{5}$ Mundakir, Komunikasi Pelayanan Kesehatan, (Yogyakarta: Indomedia Pustaka, 2016), h. 166-169.

Al Qalam: Jurnal Ilmiah Keagamaan dan Kemasyarakatan Vol. 16, No. 2 Maret - April 2022 
Zulfikar : Komunikasi Teurapeutik Dewan Guru Dalam Membina Santri Yang Melanggar Peraturan (Studi di Jamiah Al-Aiziyah Desa Batee Iliek Kecamatan Samalanga)

baik dan memberi kesempatan pada mereka untuk mengekpresikan perasaannya, pikiran dan sikapnya, (2) Mengajak remaja berdiskusi terkait dengan perasaan, pikiran dan sikapnya, (3) Jangan memotong pembicaraan dan jangan berkomentar atau berespons yang berlebihan pada saat remaja menunjukkan sikap emosional, maka sikpa remaja kita adalah memberikan support atas segala masalah yang dihadapi remaja dan membantu untuk menyelasaikan dengan mendikusikannya, (4) Perawat atau orang dewasa lain harus dapat menjadi sahabat buat remaja, tempat berbagi cerita suka dan duka, (5) Duduk bersama remaja, memeluk, merangkul, mengobrol, dan bercengkerama dengan mereka serta sering melakukan maka bersama. ${ }^{6}$

Selain itu juga ada buku Nadra Ideyani Vita yang menjelaskan bahwa komunikasi terapeutik dialogis yang disajikan dalam bukunya itu menjelaskan tentang pendalaman terhadap situasi dan perilaku dokter di rumah sakit daerah dan rumah sakit luar negeri yaitu Malaysia serta pengalaman paisen yang menjalani layanan kesehatan di rumah sakit daerah dan rumah sakit Malaysia. Pada akhirnya komunikasi verbal dan komunikasi non verbal dapat mendorong kesembuhan pasien melalui komunikasi dialogis. ${ }^{7}$

Selain buku juga ada beberapa jurnal yang membahas tentang komunikasi terapeutik di antaranya seperti jurnal yang ditulis oleh Ayu Astika Sari dkk yang menjelaskan beberapa teknik komunikasi terapeutik yang perlu diterapkan oleh seorang dokter terhadap pasiennya yaitu : (1) Menunjukkan Penerimaan, (2) Berpenampilan Rapi, (3) Kontak Mata dan Sentuhan, (4) Mendengarkan, (5) Klarifikasi, (6) Pertanyaan Terbuka dan Pertanyaan Tertutup dan (7) Menyampaikan Hasil Observasi. ${ }^{8}$

Selain itu juga ada jurnal yang ditulis oleh Rudi Hartono yang menjelaskan bahwa proses komunikasi terapeutik selama pandemi Covid-19 harus tetap diterapkan, walaupun banyak hambatan dan juga rintangan. Komunikasi terapeutik dapat meminimilisir rasa cemas, takut dan khawatir yang dirasakan pasien dan keluarga. Penggunaan komunikasi terapeutik ini prtlu ditunjang dengan prinsip, teknik dan strategi guna mencapai kesembuhan pasien. Kualitas dari komunikasi pun harus terjaga agar menghasilkan output yang baik. Kualitas komunikasi terapeutik

${ }^{6}$ Tri Anjaswani, Komunikasi Dalam Keperawatan, (Jakarta : Kementrian Kesehatan Republik Indonesia, 2016), h. 129.

${ }^{7}$ Nadra Ideyani Vita, Komunikasi Terapeutik Dialogis, (Surabaya : Scopindo Media Pustaka, 2021), h. 87 .

${ }^{8}$ Ayu Astika Sari R, dkk, Penerapan Komunikasi Terapeutik dalam Pelayanan Kesehatan (Studi Komunikasi Terapeutik Dokter Spesialis Obstertri dan Ginekologi dengan Pasien Ibu Hamil Pada Praktik Dikter Bersama di Apotel Al-Khair Bengkulu, (Jurnal Kaganga, Volume 3 Nomor 1, April 2019), h. 18-19.

Al Qalam: Jurnal Ilmiah Keagamaan dan Kemasyarakatan Vol. 16, No. 2 Maret - April 2022 
Zulfikar : Komunikasi Teurapeutik Dewan Guru Dalam Membina Santri Yang Melanggar Peraturan (Studi di Jamiah Al-Aiziyah Desa Batee Iliek Kecamatan Samalanga)

ditentukan oleh bagaimana perawat dapat memahami diri, mengelola emosi dan knowlwdge yang dimiliki. $^{9}$

Dari beberapa buku dan jurnal yang membahas tentang komunikasi terapeutik antara perawat dengan pasien atau keluarga pasien, belum ada literatur yang membahas tentang komunikasi terapeutik dewan guru dalam menanggani santri yang melanggar di dayah atau pesantren. Maka dalam hal ini komunikasi terapeutik dewan guru dayah atau pesantren dalam menanggani santri yang melanggar merupakan penelitian yang layak untuk dilakukan, karena itu menjadi sebuah penelitian baru dalam bidang ilmu komunikasi terapeutik .

Komunikasi terapeutik yang dilakukan oleh dewan guru dayah atau pesantren merupakan langkah maju bagi dunia pendidikan dayah, sehingga akan memberikan sebuah jawaban terhadap problem yang terjadi di dayah atau pesantren selama ini. Di Dayah Jamiah Al-Aziziyah komunikasi terapeutik merupakan hal perlu dilakukan oleh dewan guru dayah atau pesantren karena banyak santri yang melakukan pelanggaran perlu diberikan pemahaman dan dicari akar permasalahan yang dihadapi oleh santri selama dilingkungan dayah.

\section{METODE PENELITIAN}

\section{Jenis Penelitian}

Metode penelitian yang digunakan peneliti dalam penelitain mengenai komunikasi terapeutik dewan guru dalam menanggani santri yang melanggar peraturan di dayah atau pesantren adalah pendekatan kualitatif dengan metode studi kasus. ${ }^{10}$ Studi kasus merupakan uraian dan penjelasan komprehensif mengenai berbagai aspek seorang individu, suatu kelompok, atau organisasi, suatu program, atau suatu situasi sosial. Penelitian studi kasus berupaya menelaah sebanyak mungkin data mengenai subjek yang diteliti. Dalam hal ini, data tersebut ditemukan melalui wawancara mendalam, pengamatan, penelaahan dokumen hasil survey, dan data apa pun untuk diuraikan secera terperinci.

Penelitian ini bertempat di Dayah Jamiah Al-Aziziyah Desa Batee Iliek Kecamatan Samalanga Kabupaten Bireuen Provinsi Aceh. Alasan memilih dayah tersebut sebagai lokasi penelitian adalah karena di dayah tersebut selama ini banyak terjadi permasalahan antara santri dengan dewan guru dalam menjalan aturan yang di dayah tersebut, sehingga perlu dicarikan jalan keluar atau solusi yang terbaik bagi santri dan dewan guru melalui komunikasi terapeutik.

\footnotetext{
${ }^{9}$ Veronika Fernanda Dua Hiko, Dkk, Pelaksanaan Komunikasi Terapeutik Perawat Era Covid-19, (Jurnal Ilmiah Permas: Jurnal Ilmiah STIKES Kendal, Vol. 11, No. 4, Oktober 2021), h. 736.

${ }^{10}$ Deddy Mulyana, Metodologi Penelitian Komunikasi, (Bandung : Remaja Rosdakarya, 2008), h. 201.
}

Al Qalam: Jurnal Ilmiah Keagamaan dan Kemasyarakatan Vol. 16, No. 2 Maret - April 2022 
Zulfikar : Komunikasi Teurapeutik Dewan Guru Dalam Membina Santri Yang Melanggar Peraturan (Studi di Jamiah Al-Aiziyah Desa Batee Iliek Kecamatan Samalanga)

\section{HASIL DAN PEMBAHASAN}

\section{Tinjauan Komunikasi Terapeutik}

Komunikasi terapeutik menurut G.W merupakan hubungan interpersonal antara konselor dan klien melalui hubungan ini, konselor dan klien memperoleh pengalaman belajar bersama dalam rangka memperbaiki pengalaman emocional klien. ${ }^{11}$ Menurut Suryani sebagaimana dikutip oleh Etik Anjar Fitriarti komunikasi terapeutik adalah kemampuan atau keterampilan konselor untuk membantu klien beradaptasi terhadap stress, mengatasi gangguan psikologis, serta belajar bagaimana berhubungan dengan orang lain. ${ }^{12}$

Komunikasi terapeutik bukan tentang apa yang dilakukan oleh seorang perawat, tetapi bagaimana perawat itu melakukan komunikasi dengan pasien serta mengembangkan hubungan yang saling membantu antara perawat dengan pasien yang dengan tujuan untuk kesembuhan pasien tersebut. ${ }^{13}$ Salah satu hal yang perlu dilakukan perawat dalam menjaga kerjasama yang baik dengan pasien dalam membantu mengatasi masalah pasien adalah dengan berkomunikasi. Dengan komunikasi perawat dapat mendengarkan perasaan pasien dan menjelaskan prosedur tindakan keperawatan. ${ }^{14}$ Komunikasi perawat dengan pasien memegang peranan pnting dalam membantu pasien memecahkan masalah yang dihadapi. Diharuskan seorang perawat di ruang Neurologi menerapkan kemampuannya dalam berkomunikasi terapeutik secara efektif ketika melayani pasien, karena tujuan dari komunikasi terapeutik adalah untuk kesembunan pasien itu sendiri.

Menurut Suryani sebagaimana dikutip oleh Etik Anjar Fitriarti bahwa komunikasi terapeutik bertujuan untuk mengembangkan pribadi klien kearah yang lebih positif atau adaktif. Adapun tujuan lain dari komunikasi terapeutik itu yaitu: ${ }^{15}$ (1) Realisiasi diri, penerimaan diri, dan peningkatan penghormatan komunikasi terapeutik diharapkan dapat mengubah sikap dan perilaku klien. Klien yang merasa rendah diri, setelah berkomunikasi terapeutik dengan konselor akan mampu menerima dirinya, (2) Kemampuan membina hubungan interpersonal yang tidak super fsisial dan saling bergantung dengan orang lain melalui komunikasi terapeutik, klien belajar cara menerima dan diterima orang lain, (3) Peningkatan fungsi dan kemampuan untuk memuaskan

\footnotetext{
${ }^{11}$ Abdul Nasir,et al, Komunikasi Dalam Keperawatan Teori dan Aplikasi, (Jakarta : Salemba Medika, 2009), h. 143.

${ }^{12}$ Etik Anjar Fitriarti, Komunikasi Terapeutik Dalam Konseling, Skripsi, (Yogyakrta : Fakultas Ilmu Sosial dan Humaniora Universitas Islam Negeri Sunan Kalijaga)

${ }^{13}$ Suryani, Komunikasi Terapeutik Teori dan Praktik, (Jakarta : EGC, 2006), h. 152.

${ }^{14}$ Mundakir, Komunikasi Keperawatan Aplikasi Dalam Pelayanan, (Yogyakarta: Grahal Ilmu Muhazam, 2010), F. 1995. Memperkenalkan Sosiologi Kesehatan, Jakarta : UI Press), 010), h. 125.

${ }^{15}$ Etik Anjar Fitriarti, Komunikasi Terapeutik Dalam Konseling...,
}

Al Qalam: Jurnal Ilmiah Keagamaan dan Kemasyarakatan Vol. 16, No. 2 Maret - April 2022 
Zulfikar : Komunikasi Teurapeutik Dewan Guru Dalam Membina Santri Yang Melanggar Peraturan (Studi di Jamiah Al-Aiziyah Desa Batee Iliek Kecamatan Samalanga)

kebutuhan serta mencapai tujuan yang realistic klien terkadang menetapkan standar diri terlalui ringgi tanpa mengukur kemampuannya sehingga ketika tujuannya tidak tercapai klien akan merasa rendah diri dan kondisinya memburuk, (4) Peningkatan idenditas dan integritas diri keadaan sakit terlalu lama cenderung menyebabkan klien mengalami gangguan idenditas dan integritas dirinya sehingga tidak memiliki rasa percaya diri dan merasa rendah diri.

Strategi komunikasi menurut peneliti adalah cara atau taktik yang menyeluruh dari rangkaian tindakan yang akan dilaksanakan oleh sebuah organisasi untuk mencapai suatu tujuan atau beberapa sasaran dengan memiliki sebuah panduan perencanaan dan manajemen komunikasi untuk mencapai tujuan yang telah ditetapkan. Sedangkan organisasi adalah sebuah lembaga atau perkumpulan yang dibangun oleh beberapa orang dengan tujuan agar organisasi atau lembaga itu bisa mencapai sebuah tujuan yang telah sama-sama disepakati pada awal pembentukan sebuah organisasi atau lembaga. Dimana masing-masing pengurus organisasi memiliki peran masingmasing dalam upaya mencapai target yang dibebankan kepada mereka dalam upaya menjaga supaya organisasi tetap hidup dan berjalan sebagaimana mestinya.

2. Komunikasi Terapeutik Dewan Guru Dayah Jamiah Al-Aziziyah dalam menanggani santri yang melanggar

a. Jenis-jenis pelanggaran santri di Dayah Jamiah Al-Aziziyah

Pelanggaran yang biasa dilakukan oleh para santri di Dayah Jamiah Al-Aziziyah selama ini antara lain : ${ }^{16}$

1) Membulli kawan

Salah satu peraturan yang tidak boleh dilakukan oleh santri Dayah Jamiah Al-Aziziyah adalah melakukan bulli terhadap teman, baik itu teman sesama santri yang baru maupun teman yang berupa abang letting dengan adik letting seperti yang sering kita lihat di dayah atau pesantren pada umumnya. Jika ada santri yang melakukan bulli terhadap kawannya maka santri itu akan diberikan peringatan secara lisan pertama kali, jika masih mengulang perbuatannya maka akan dipanggil orangtuanya ke dayah untuk diberikan peringatan secara tertulis dan jika masih mengulang kembali maka akan dikeluarkan dari dayah.

2) Berkelahi

Perkelahian antara santri dalam sebuah dayah atau pesantren merupakan sesuatu yang sering kita lihat dan kita baca dikoran-koran, sehingga itu menjadi sebuah perhatian bagi pengelolan dayah dan dewan guru. Berkelahi dengan sesama santri di Dayah Jamiah Al-Aziziyah juga dianggap

\footnotetext{
${ }^{16}$ Wawancara dengan Teungku Abdul Aziz Kabag Humas Dayah Jamiah Al-Aziziyah, pada Tanggal 20 Agustus 2020, jam 10.30 wib.
}

Al Qalam: Jurnal Ilmiah Keagamaan dan Kemasyarakatan Vol. 16, No. 2 Maret - April 2022 
Zulfikar : Komunikasi Teurapeutik Dewan Guru Dalam Membina Santri Yang Melanggar Peraturan (Studi di Jamiah Al-Aiziyah Desa Batee Iliek Kecamatan Samalanga)

sebagai salah satu bentuk pelanggaran berat, santri yang berkelahi dengan guru akan dikeluarkan dengan tanpa hormat. Sedangkan santri yang berkelahi dengan sesame santri akan diberi peringatan lisan, tertulis dan terakhir akan dikeluarkan dari dayah atau pesantren.

3) Merokok

Perbuatan merokok merupakan salah satu bentuk pelanggaran berat bagi santri Dayah Jamiah AlAziziyah, sehingga bila ada santri yang kedapatan membeli/menyimpan rokok atau merokok maka akan diberikan peringatan lisan, tertulis dan juga akan dikeluarkan bila tidak ada perubahan sama sekali. Di Dayah Jamiah Al-Aziziyah sudah ada peraturan tertulis bahwa merokok itu haram bagi dewan guru dan santri, jika ada dewan guru yang merokok dan kedapatan sama pimpinan maka dewan guru akan diberikan peringatan keras dan hal sama juga berlaku bagi santri.

4) Mencuri

Salah satu alasan santri melakukan pencurian adalah karena kehabisan uang yang dikirim oleh orangtua mereka, maka jika ada santri yang melakukan perbuatan pencurian akan diberikan peringatan lisan, tulisan dan juga dikeluarkan jika tidak ada perubahan sama sekali. Mencuri merupakan salah satu pelanggaran yang tidak dimaafkan di Dayah Jamiah Al-Aziziyah, karena perbuatan itu sangat merugikan orang lain dan membuat citra nama dayah akan tidak bagus dimata masyarakat.

5) Keluar komplek tanpa izin

Santri dilarang keluar komplek tanpa izin dari petugas yang sudah ditetapkan oleh pihak bagian humas, apalagi jika itu dilakukan pada malam hari dan dari pintu belakang atau melompati pagar. Bagi santri yang ketahuan keluar komplek maka akan diberikan teguran lisan, teguran tertulis dan akan dirumahkan jika tidak ada perubahan sama sekali, karena keluar komplek tanpa izin di Dayah Jamiah Al-Aziziyah merupakan perbuatan yang dikatagorikan pelanggaran berat.

6) Tidak Mengaji

Bagi santri yang tidak naik ngaji pada jam belajar pagi siang dan malam, maka santri itu akan diberikan peringatan lisan, jika masih mengulangi perbuatannya maka akan diberikan peringatan tulisan dengan memanggil orangtuanya kedayah. Tidak naik ngaji dengan tanpa ada surat izin dari guru kelas merupakan sebuah bentuk pelanggaran yang tidak bisa dimaafkan, karena akan menganggu aktifitas belajar dan mengajar di Dayah Jamiah Al-Aziziyah serta menyebakan kepada bentuk pelanggaran yang lain.

7) Memakai HP

Bagi santri Dayah Jamiah Al-Aziziyah yang masih belum berstatus dewan guru atau kuliah maka dilarang untuk membawa HandPhone (HP) ke dalam komplek dayah, karena itu merupakan salah

Al Qalam: Jurnal Ilmiah Keagamaan dan Kemasyarakatan Vol. 16, No. 2 Maret - April 2022 
Zulfikar : Komunikasi Teurapeutik Dewan Guru Dalam Membina Santri Yang Melanggar Peraturan (Studi di Jamiah Al-Aiziyah Desa Batee Iliek Kecamatan Samalanga)

satu bentuk pelanggaran berat. Bagi santri yang kedapatan membawa HP dan menyimpan dilemarinya maka akan diambil oleh pihak Humas dan dikembalikan kepada orangtua santri dengan catatan tidak boleh diberikan lagi kepada anaknya. Jika kedapatan membawa HP pada kali kedua maka HP itu akan dihancurkan oleh Humas dan tidak dikembalikan lagi kepada santri maupun orangtua santri.

b. Bentuk-bentuk komunikasi terapeutik yang dilakukan oleh pihak Humas Dayah Jamiah AlAziziyah

1) Mendengar

Pihak Humas Dayah Jamiah Al-Aziziyah jika kedapatan ada santri yang melanggar peraturan yang sudah ditetapkan, maka santri tersebut akan dipanggil terlebih dahulu ke kantor Humas dan akan ditanyakan alasan kenapa dia melakukan perbuatan pelanggaran. Setelah mendengar pengakuan dari santri yang melakukan pelanggaran tersebut, maka pihak Humas akan melakukan kajian kebenaran terhadap apa yang dikatakan oleh santri sehingga tidak salah dalam mengambil keputusan karena banyak santri yang berbohong pada saat memberikan pengakuan. ${ }^{17}$

2) Bertanya

Ketika pihak Humas melakukan pemeriksaan terhadap santri yang melakukan pelanggaran, maka pihak Humas akan bertanya dengan baik kepada santri kenapa dia melakukan pelanggaran. Dalam hal ini bertanya merupakan salah satu bentuk untuk memberikan kesempatan kepada santri untuk mengungkapkan perasaannya yang selama ini terpendam, sehingga akan memberikan sebuah penjelasan dan pengakuan yang sebenarnya apa yang telah terjadi. Dalam hal bertanya kepada santri yang melakukan pelanggaran pada tahap pertama dilakukan dengan lembut dan jika tidak menemukan jawaban yang sesuai maka dilakukan dengan sedikit keras dan membantak supaya lahir kejadian sebenarnya. ${ }^{18}$

3) Penerimaan

Pihak Humas Dayah Jamiah Al-Aziziyah dalam hal menangani santri yang telah melakukan pelanggaran maka santri itu harus diterima dengan kata-kata yang lembut dan tutur kata yang sopan, supaya santri itu mau memberikan pernyataan yang sebenarnya. Penerimaan dalam hal ini adalah mau mendengarkan apa yang dikataka oleh santri yang melanggar, walaupun pihak Humas

\footnotetext{
${ }^{17}$ Wawancara dengan Teungku Aulia Saputra anggota Humas Dayah Jamiah Al-Aziziyah, pada Tanggal 21 Agustus 2020, jam 08.00 wib.

${ }^{18}$ Wawancara dengan Teungku Hafidh anggota Humas Dayah Jamiah Al-Aziziyah, pada Tanggal 21 Agustus 2020, jam 09.30 wib.
}

Al Qalam: Jurnal Ilmiah Keagamaan dan Kemasyarakatan Vol. 16, No. 2 Maret - April 2022 
Zulfikar : Komunikasi Teurapeutik Dewan Guru Dalam Membina Santri Yang Melanggar Peraturan (Studi di Jamiah Al-Aiziyah Desa Batee Iliek Kecamatan Samalanga)

sudah tahu bagaimana kejadian yang sebenarnya. Penerimaan disini bukan untuk pembenaran tetapi hanya untuk sebatas mendapatkan informasi semata-mata. ${ }^{19}$

4) Mengulangi (Restating)

Pihak Humas Dayah Jamiah Al-Aziziyah akan mengulangi segala bentuk perkataan dan pernyataan yang sudah dikatakan oleh santri yang melanggar peraturan, sehingga ini akan memberikan pemahaman bahwa santri yang melanggar diberikan perhatian dan dukungan terhadap persoalan yang dia lakukan, dengan begitu akan semakin mudah bagi pihak Humas untuk mengungkapkan kejadian yang sebenarnya terjadi atau apa yang melatarbelakangi santri tersebut melakukan pelanggaran itu dengan secara sendiri atau dibantu oleh orang lain. ${ }^{20}$

5) Klarifikasi (Clarificion)

Setelah santri yang melakukan pelanggaran memberikan penjelasan atau kesaksian terhadap perbuatan yang ia lakukan, maka selanjutnya bagi pihak Humas Dayah Jamiah Al-Aziziyah melakukan klarifikasi terhadap apa yang sudah didengarkan dari santri yang melanggar. Klarifikasi ini nantinya akan memberikan penjelasan lebih lanjut atau akan mendapatkan jawaban yang lain dari santri yang melakukan pelanggaran, sehingga itu akan memudahkan pihak Humas dalam melakukan penyelidikan. ${ }^{21}$

6) Memfokuskan (Focusing)

Setelah mendapatkan titik temu terhadap persoalan santri yang melanggar, maka pihak Humas Dayah Jamiah Al-Aziziyah selanjutnya akan fokus pada apa yang mereka daptkan dari pengakuan santri yang melakukan pelanggaran. Fokus disini adalah untuk mengarahkan pembicaraan kepada satu maksud dan tujuan dan tidak melebar kemana-mana, sehingga persoalan santri itu akan cepat selesai dan tidak berlarut-larut. ${ }^{22}$

7) Diam (Silence)

Diam yang dimaksudkan di sini adalah bahwa pihak Humas Dayah Jamiah Al-Aziziyah harus memberikan waktu kepada santri yang melanggar untuk memikirkan jawaban yang akan diberikan kepada pihak Humas, sehingga itu memudahkan santri dalam berpikir dan mengingat bentuk

${ }^{19}$ Wawancara dengan Teungku Khairul Umam anggota Humas Dayah Jamiah Al-Aziziyah, pada Tanggal 21 Agustus 2020, jam 10.00 wib.

${ }^{20}$ Wawancara dengan Teungku Suhaimi anggota Humas Dayah Jamiah Al-Aziziyah, pada Tanggal 22 Agustus 2020, jam 08.00 wib.

${ }^{21}$ Wawancara dengan Teungku Reza Asratuzzur anggota Humas Dayah Jamiah Al-Aziziyah, pada Tanggal 22 Agustus 2020, jam 09.30 wib.

${ }^{22}$ Wawancara dengan Teungku Riadhi Arijuddin anggota Humas Dayah Jamiah Al-Aziziyah, pada Tanggal 22 Agustus 2020, jam 10.00 wib.

Al Qalam: Jurnal Ilmiah Keagamaan dan Kemasyarakatan Vol. 16, No. 2 Maret - April 2022 
Zulfikar : Komunikasi Teurapeutik Dewan Guru Dalam Membina Santri Yang Melanggar Peraturan (Studi di Jamiah Al-Aiziyah Desa Batee Iliek Kecamatan Samalanga)

kejadian yang dia lakukan. Diam itu akan memberikan waktu kepada santri untuk berkata yang sebenarnya dan juga akan membuat santri menjadi hati-hati dalam memberikan jawaban. ${ }^{23}$

8) Memberikan Informasi (Informing)

Pihak Humas dalam melakukan pemeriksaan juga harus punya informasi awal supaya itu memudahkan bagi santri dalam menjawab segala pertanyaan yang diatanyakan oleh pihak Humas, sehingga tidak membuat santri salah dalam memberikan jawaban. Memberikan informasi dalam hal ini adalah informasi tambahan terhadap apa yang dikatakan oleh santri, supaya memberikan solusi dan titik temu dalam melakukan pemerikasaan. ${ }^{24}$

9) Menyimpulkan (Summerizing)

Menyimpulkan permasalahan merupakan salah satu cara untuk membantu santri dalam memberikan informasi, sehingga akan memberikan sebuah kesimpulan yang disetujui bersama. Penyimpulan ini harus sesuai dengan persepsi kedua belah pihak, supaya tidak ada pihak merasa dirugikan dan disalahkan nantinya. Kesumpulan yang disepakati nantinya tidak bisa dirubah lagi dengan alasan apapun, karena itu akan menimbulkan persoalan baru dikemudian hari. ${ }^{25}$

10) Mengubah cara pandang (Reframing)

Perubahan cara pandang yang diberikan oleh pihak Humas Dayah Jamiah Al-Aziziyah akan membuat santri yang melakukan pelanggaran akan menyadari bahwa apa yang dia lakukan akan membawa efek yang tidak baik serta akan merugikan orang lain. Metode ini akan memberikan perubahan sikap dan pola piker santri yang melanggar peraturan, sehingga dia tidak akan menyalahkan orang lain lagi. ${ }^{26}$

11) Humor

Selain mendengar apa yang disampaikan oleh santri yang melanggar peraturan, maka pihak Humas Dayah Jamiah Al-Aziziyah dalam menanggapi apa yang disampaikan oleh santri dengan cara yang penuh humor. Dengan begitu maka santri tidak akan merasa ketakutan dalam memberikan informasi serta tidak akan kaku dalam menjawab segala pertanyaan yang diajukan oleh pihak Humas kepadanya dan memudahkan santri dalam memberikan penjelasan lebih lanjut tentang persoalan yang dia hadapi selama ini. ${ }^{27}$

12) Memberikan pujian (Reiforcement)

\footnotetext{
${ }^{23}$ Wawancara dengan Teungku Hafidh,... pada Tanggal 21 Agustus 2020, jam 09.30 wib.

${ }^{24}$ Wawancara dengan Teungku Khairul Umam,... pada Tanggal 21 Agustus 2020, jam 10.00 wib.

${ }^{25}$ Wawancara dengan Teungku Suhaimi,... pada Tanggal 22 Agustus 2020, jam 08.00 wib.

${ }^{26}$ Wawancara dengan Teungku Reza Asratuzzur,... pada Tanggal 22 Agustus 2020, jam 09.30 wib.

${ }^{27}$ Wawancara dengan Teungku Riadhi Arijuddin,... pada Tanggal 22 Agustus 2020, jam 10.00 wib.
}

Al Qalam: Jurnal Ilmiah Keagamaan dan Kemasyarakatan Vol. 16, No. 2 Maret - April 2022 
Zulfikar : Komunikasi Teurapeutik Dewan Guru Dalam Membina Santri Yang Melanggar Peraturan (Studi di Jamiah Al-Aiziyah Desa Batee Iliek Kecamatan Samalanga)

Pujian yang diberikan oleh pihak Humas Dayah Jamiah Al-Aziziyah kepada santri yang melanggar tentunya dalam bentuk kewajaran, sehingga akan membuat santri yang melanggar akan semakin kuat dalam memberikan informasi. Sehingga apa yang disampaikan oleh santri nantinya akan menjadi sebuah saluran dalam meluapkan segala emosi yang selama ini terpendam, dengan begitu akan semakin bagi pihak Humas dalam memperoleh informasi dari santri tersebut. ${ }^{28}$

Komunikasi terapeutik yang dipraktikkan oleh pihak Humas Dayah Jamiah Al-Aziziyah selama ini sangat memudahkan bagi mereka dalam menangani berbagai kasus pelanggaran yang dilakukan oleh para santri, sehingga dengan begitu memberikan ilmu tambahan bagi pihak Humas dalam melakukan klarifikasi dan menyimpulkan informasi dari para santri yang melakukan pelanggaran. Kalau dalam ilmu keperawatan komunikasi terapeutik untuk memudahkan komunikasi perawat dengan pasien, maka dalam bidang pengelolan dayah memudahkan pihak Humas dalam memperoleh informasi dari para santri yang melakukan pelanggaran terhadap peraturan di Dayah Jamiah Al-Aziziyah.

\section{PENUTUP}

Komunikasi terapeutik sangat bagus jika dipakai oleh sebuah lembaga pendidikan seperti dayah atau pesantren, karena dengan adanya komunikasi terapeutik akan semakin mudah dalam menangani santri-santri yang melakukan pelanggaran dalam hal mencari informasi atau menyimpulkannya. Penguasaan komunikasi terapeutik bagi pihak Humas Dayah Jamiah AlAziziyah merupakan sesuatu hal yang luar biasa karena itu memberikan kemudahan bagi pihak Humas dalam menghadapi persoalan-persoalan yang terjadi di Dayah Jamiah Al-Aziziyah.

Komunikasi terapeutik merupakan salah satu ilmu komunikasi untuk mempelajari apa yang sebenarnya terjadi dan juga ilmu untuk memberikan solusi terhadap persoalan yang sedang dihadapi. Baik itu yang menyangkut antara perawat dengan pasiennya maupun yang dilakukan oleh pihak Humas dalam mencari titik persoalan yang terjadi di dayah yang mereka naungi. Komunikasi terapeutik akan memberikan solusi dalam menangani persoalan santri yang melakukan pelanggaran dengan cara menggali informasi dan memberikan perlindungan kepadanya. Sehingga akan membuat santri yang melanggar merasa terlindungi dan bebas dalam menyampaikan segala informasi kepada pihak Humas Dayah Jamiah Al-Aziziyah, dengan begitu pihak Humas tidak perlu menggunakan jalan kekerasan apalagi jalur hukum dalam menangani segala bentuk persoalan yang terjadi di Dayah Jamiah Al-Aziziyah.

${ }^{28}$ Wawancara dengan Teungku Abdul Aziz,... pada Tanggal 20 Agustus 2020, jam 10.30 wib.

Al Qalam: Jurnal Ilmiah Keagamaan dan Kemasyarakatan Vol. 16, No. 2 Maret - April 2022 
Zulfikar : Komunikasi Teurapeutik Dewan Guru Dalam Membina Santri Yang Melanggar Peraturan (Studi di Jamiah Al-Aiziyah Desa Batee Iliek Kecamatan Samalanga)

\section{DAFTAR PUSTAKA}

Abdul Nasir,et al, Komunikasi Dalam Keperawatan Teori dan Aplikasi, (Jakarta : Salemba Medika, 2009), h. 143.

Abidin, Y.Z, Manajemen Komunikasi, (Filosofi, Konsep dan Aplikasi), Bandung: Pustaka Setia, 2015.

Anas Tamsuri, Komunikasi dalam Keperawatan, Jakarta: Penerbit Buku Kedokteran EGC, 2004

Arifuddin Tike, Dasar-dasar Komunikasi : Suatu Studi dan Aplikasi, Yogyakarta : Kota Kembang, 2009

Arni Muhammad, Komunikasi Organisasi, Jakarta: Bumi Aksara, 2011.

Ayu Astika Sari R, dkk, Penerapan Komunikasi Terapeutik dalam Pelayanan Kesehatan (Studi Komunikasi Terapeutik Dokter Spesialis Obstertri dan Ginekologi dengan Pasien Ibu Hamil Pada Praktik Dikter Bersama di Apotel Al-Khair Bengkulu, Jurnal Kaganga, Volume 3 Nomor 1, April 2019.

Bungin, Bungin. Penelitian Kualitatif, Jakarta : Kencana Prenada Media Group, 2007.

Etik Anjar Fitriarti, Komunikasi Terapeutik Dalam Konseling, Skripsi, (Yogyakrta : Fakultas Ilmu Sosial dan Humaniora Universitas Islam Negeri Sunan Kalijaga)

Mulyana, Deddy. Ilmu Komunikasi Suatu Pengantar, Bandung: Remaja Rosdakarya, 2002.

Mulyana, Deddy. Metodologi Penelitian Komunikasi, Bandung : Remaja Rosdakarya, 2008.

Mundakir, Komunikasi Keperawatan Aplikasi Dalam Pelayanan, Yogyakarta: Grahal Ilmu Muhazam, 2010), F. 1995. Memperkenalkan Sosiologi Kesehatan, Jakarta : UI Press.

Mundakir, Komunikasi Pelayanan Kesehatan, Yogyakarta : Indomedia Pustaka, 2016.

Nadra Ideyani Vita, Komunikasi Terapeutik Dialogis, Surabaya : Scopindo Media Pustaka, 2021

Robert K. Yin, Studi Kasus (Desain dan Metode), Jakarta : Raja Grafindo Persada, 2002.

Suryani, Komunikasi Terapeutik Teori dan Praktik, Jakarta : EGC, 2006.

Tri Anjaswani, Komunikasi Dalam Keperawatan, Jakarta : Kementrian Kesehatan Republik Indonesia, 2016.

Veronika Fernanda Dua Hiko, Dkk, Pelaksanaan Komunikasi Terapeutik Perawat Era Covid-19, Jurnal Ilmiah Permas: Jurnal Ilmiah STIKES Kendal, Vol. 11, No. 4, Oktober 2021.

Al Qalam: Jurnal Ilmiah Keagamaan dan Kemasyarakatan Vol. 16, No. 2 Maret - April 2022 